Journal of Engineering and Applied Sciences 15 (4): 982-989, 2020

ISSN: 1816-949X

(C) Medwell Journals, 2020

\title{
The Compressive Strength of Concrete-Backed Stone Masonry Small Size Prisms
}

\author{
Nart Mawloud Abdel-Qader Naghoj \\ Department of Civil Engineering, Faculty of Engineering Technology, \\ Al Balqa Applied University, 11134 Marka, Amman, Jordan
}

\begin{abstract}
This study aims to present the results of a test programme taken onsmall size concrete-backed stone prisms built with medium-density limestone. The effect of the size of the prisms on the ultimate compressive strength was studied. The behaviour of prisms until failure was also studied. Large numbers of small size prisms with different thicknesses, widths and same mortar joint thickness and mix proportions for either mortar or concrete were tested in compression. Two groups of stone were adopted in constructing the prisms, the first group was built using regular stone thickness and the other group with irregular thickness. The test results express a significant increase in compressive strength when small prisms were built from stone units with regular thicknesses.
\end{abstract}

Key words: Masonry, compressive strength, small prisms, stone thickness, medium-density limestone, concrete, mortar joint

\section{INTRODUCTION}

In some middle Eastern countries, especially, Jordan and until the $1990 \mathrm{~s}$, low-rise buildings were mainly constructed using concrete-backed stone as structural elements where walls were used as load bearing elements.

A study previously carried out on the structure evolution of concrete-backed stone masonry suggested that the weakest point in the concrete-backed stone masonry is in the adhesion between the stones and the concrete. Due to this weak bond between the concrete and the stones, stones at failure did not compare favorably with the comprehensive strength of the concrete or the stone units (Abdel-Halim et al., 1989).

The researcher (Abdel Qader, 2002; Naghoj, 2013) conducted a study on concrete-backed stone masonry prisms which demonstrated that the effect of the height to width ratio is not significant in the changing of the ultimate comprehensive strength of the prisms with a height to width ratio ranging from 1.6 (three course height prisms) to 3.25 (six course height prisms) tested under concentric load which is for prisms built from either stone mortar or concrete of the same compressive strength.

The purpose of conducting this study is to find an alternative method of testing large scale walls and columns through their smaller counterparts. This is by testing small sized prisms that could indicate the strength of the full-scale walls and columns.

\section{MATERIALS AND METHODS}

Stones: Stone units were manufactured from limestone materials which brought from five different quarries. A medium density type of limestone units was used which classified by ASTM C 568-89 (1992) as category II (Medium-density), that's for limestone having a density $>2160 \mathrm{~kg} \mathrm{~m}^{-3}$ and $\geq 2560 \mathrm{~kg} \mathrm{~m}^{-3}$. The limestone compressive strength was obtained by testing $60 \times 60 \times 60 \mathrm{~mm}$ cubes in axial compression in accordance with (ASTM C 170-90, 1992). The weight percentage absorption was carried in accordance to (ASTMC 97-90, 1992).

Table 1 gives the results of the compressive strength, the weight percentage absorption and the density of tested limestone units.

Mortar: A mortar mix with 1:3 (cement: sand) batched by volume was adopted in constructing all the prisms, three $102 \times 102 \times 102 \mathrm{~mm}$ cubes were casted with each batch, compacted, then cured in a water tank, tested in compression after 28 days. The average compressive strength for the mortar was $21.5 \mathrm{~N} \mathrm{~mm}^{-2}$.

Table 1: Some important properties for stone samples

\begin{tabular}{lccc}
$\begin{array}{l}\text { Type of stone } \\
\text { and (colour) }\end{array}$ & $\begin{array}{c}\text { Compressive } \\
\text { strength }\left(\mathrm{N} \mathrm{mm}^{-2}\right)\end{array}$ & $\begin{array}{c}\text { Water } \\
\text { absorption }(\%)\end{array}$ & $\begin{array}{c}\text { Density } \\
\left(\mathrm{kg} \mathrm{m}^{-3}\right)\end{array}$ \\
\hline 1 Yellow & 34.6 & 4.23 & 2380 \\
2 White & 47.7 & 4.86 & 2250 \\
3 White & 49.0 & 3.18 & 2260 \\
4 White & 43.4 & 1.96 & 2490 \\
5 White & 55.0 & 2.50 & 2500 \\
\hline
\end{tabular}


J. Eng. Applied Sci., 15 (4): 982-989, 2020

Table 2: Dimensions of prisms for group A (prisms built with regular thickness of stone units) with $200 \times 150 \mathrm{~mm}$ cross section

\begin{tabular}{lccccc}
\hline Prism types & $\begin{array}{c}\text { Stone unit breadth } \\
\text { (Prism breadth) a (mm) }\end{array}$ & $\begin{array}{c}\text { Stone unit } \\
\text { height b (mm) }\end{array}$ & $\begin{array}{c}\text { Stone unit } \\
\text { thickness }(\mathrm{mm})\end{array}$ & $\begin{array}{c}\text { Prism thickness } \\
\mathrm{c}(\mathrm{mm})\end{array}$ & Prism height (mm) \\
\hline $\mathrm{a}$ & 200 & 100 & 50 & 150 & 210 \\
$\mathrm{~b}$ & 200 & 100 & 50 & 150 & 320 \\
$\mathrm{c}$ & 200 & 100 & 50 & 150 & 430 \\
$\mathrm{~d}$ & 200 & 100 & 50 & 150 & 540 \\
$\mathrm{e}$ & 200 & 100 & 50 & 150 & 650 \\
\hline
\end{tabular}

Table 3: Dimensions of prisms for group A (prisms built with regular thickness of stone units) with $100 \times 150 \mathrm{~mm}$ cross section

\begin{tabular}{|c|c|c|c|c|c|}
\hline Prism type & $\begin{array}{c}\text { Stone unit breadth } \\
\text { (Prism breadth) a (mm) }\end{array}$ & $\begin{array}{c}\text { Stone unit height } \\
\mathrm{b}(\mathrm{mm})\end{array}$ & $\begin{array}{c}\text { Stone unit } \\
\text { thickness (mm) }\end{array}$ & $\begin{array}{l}\text { Prism thickness } \\
\mathrm{c}(\mathrm{mm})\end{array}$ & Prism height (mm) \\
\hline b & 100 & 100 & 50 & 150 & 320 \\
\hline Prism type & $\begin{array}{c}\text { Stone unit breadth } \\
\text { (Prism breadth) a (mm) }\end{array}$ & $\begin{array}{c}\text { Stone unit } \\
\text { height } \mathrm{b}(\mathrm{mm})\end{array}$ & $\begin{array}{c}\text { Stone unit } \\
\text { thickness (mm) }\end{array}$ & $\begin{array}{c}\text { Prism thickness } \\
c(\mathrm{~mm})\end{array}$ & Prism height (mm) \\
\hline $\bar{b}$ & 100 & 100 & 50 & 100 & 320 \\
\hline
\end{tabular}

Table 5: Dimensions of prisms for group A (prisms built with regular thickness of stone units) with $100 \times 150 \mathrm{~mm}$ cross section

\begin{tabular}{lccccc}
\hline Prism type & $\begin{array}{c}\text { Stone unit breadth } \\
\text { (Prism breadth) a (mm) }\end{array}$ & $\begin{array}{c}\text { Stone unit } \\
\text { height b }(\mathrm{mm})\end{array}$ & $\begin{array}{c}\text { Stone unit } \\
\text { thickness }(\mathrm{mm})\end{array}$ & $\begin{array}{c}\text { Prism thickness } \\
\mathrm{c}(\mathrm{mm})\end{array}$ & Prism height (mm) \\
\hline $\mathrm{b}$ & 100 & 50 & 50 & 150 & 170 \\
\hline
\end{tabular}

Table 6: Dimensions of prisms for group A (prisms built with regular thickness of stone units) with $100 \times 100 \mathrm{~mm}$ cross section

\begin{tabular}{lccccc}
\hline Prism type & $\begin{array}{c}\text { Stone unit breadth } \\
\text { (Prism breadth) a (mm) }\end{array}$ & $\begin{array}{c}\text { Stone unit } \\
\text { height b }(\mathrm{mm})\end{array}$ & $\begin{array}{c}\text { Stone unit } \\
\text { thickness }(\mathrm{mm})\end{array}$ & $\begin{array}{c}\text { Prism thickness } \\
\mathrm{c}(\mathrm{mm})\end{array}$ & Prism height (mm) \\
\hline $\mathrm{b}$ & 100 & 50 & 50 & 100 & 170 \\
$\mathrm{~b}$ & 100 & 50 & 25 & 100 & 170 \\
\hline
\end{tabular}

Table 7: Dimensions of prisms for group B (prisms built with irregular thickness of stone units) with $200 \times 150 \mathrm{~mm}$ cross section

\begin{tabular}{lccccc}
\hline Prism types & $\begin{array}{c}\text { Stone unit breadth } \\
\text { (Prism breadth) a (mm) }\end{array}$ & $\begin{array}{c}\text { Stone unit } \\
\text { height b (mm) }\end{array}$ & $\begin{array}{c}\text { Stone unit } \\
\text { thickness (mm) }\end{array}$ & $\begin{array}{c}\text { Prism thickness } \\
\mathrm{c}(\mathrm{mm})\end{array}$ & Prism height (mm) \\
\hline $\mathrm{a}$ & 200 & 100 & $25-110$ & 150 & 210 \\
$\mathrm{~b}$ & 200 & 100 & $25-110$ & 150 & 320 \\
$\mathrm{c}$ & 200 & 100 & $25-110$ & 150 & 430 \\
$\mathrm{~d}$ & 200 & 100 & $25-110$ & 150 & 540 \\
$\mathrm{e}$ & 200 & 100 & $25-110$ & 150 & 650 \\
\hline
\end{tabular}

Table 8: Dimensions of a prisms from group B (prisms built with irregular thickness of stone units) with $100 \times 150 \mathrm{~mm}$ cross section

\begin{tabular}{lccccc}
\hline Prism type & $\begin{array}{c}\text { Stone unit breadth } \\
\text { (Prism breadth) a (mm) }\end{array}$ & $\begin{array}{c}\text { Stone unit } \\
\text { height b (mm) }\end{array}$ & $\begin{array}{c}\text { Stone unit } \\
\text { thickness (mm) }\end{array}$ & $\begin{array}{c}\text { Prism thickness } \\
\mathrm{c}(\mathrm{mm})\end{array}$ & Prism height (mm) \\
\hline $\mathrm{b}$ & 100 & 100 & $15-70$ & 150 & 320 \\
\hline
\end{tabular}

Concrete: A medium strength concrete was used in the construction of all the prisms with 1:2:4 (cement: sand: aggregate) proportions. The concrete was batched by volume and mixed to a medium slump of $70 \mathrm{~mm}$, placed in wooden forms then compacted using compaction bar that commonly used to compact concrete cubes. Three $102 \times 102 \times 102 \mathrm{~mm}$ cubes were taken with each batch, compacted then cured in a water tank, tested in compression after 28 days. The average compressive strength for the tested concrete cubes was $18.9 \mathrm{~N} \mathrm{~mm}^{-2}$.

\section{Experimental programe}

Specimen construction: All prisms were built by an experienced mason. At the beginning the stones were built with $10 \mathrm{~mm}$ mortar joints. After $24 \mathrm{~h}$, the mortar was cured for 7 days by wetting it twice a day. The next step was to surround the built stones by wooden forms from three sides, after which the concrete was placed in the forms in about $100 \mathrm{~mm}$ layers, later being compacted by a compaction bar. Finally, the prisms were cured by watering them for about $5 \mathrm{~min}$ twice a day for 14 days.

The constructed prisms were divided into two groups, group A and group B. Figure 1 show the prisms that built with regular thickness of the stone units. The dimensions of the prisms are given in Tables 2-6.

Figure 2 show prisms that built with irregular thickness of stone units. The dimensions of the prisms are given in Tables 7-10. 


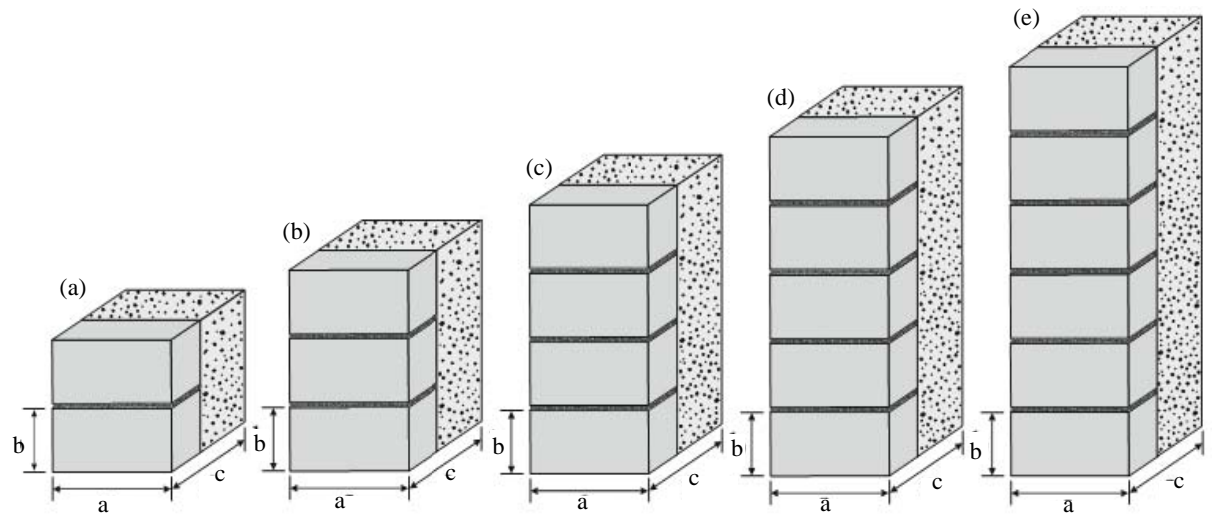

Fig. 1(a-e): Different type of prisms of group A (prisms built with regular thickness of the stone units)

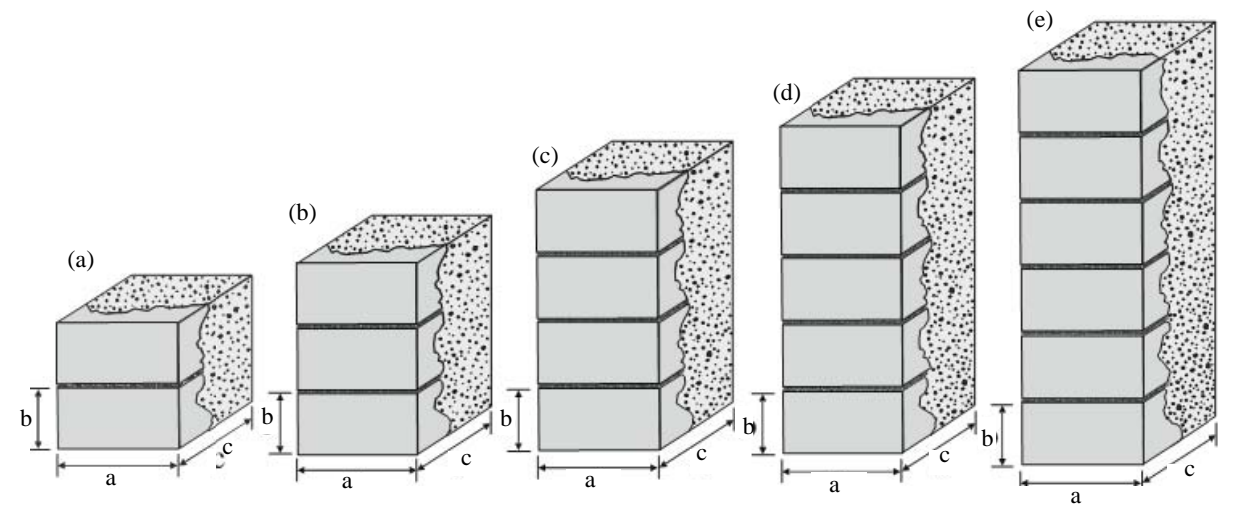

Fig. 2(a-e): Different types of prisms of group B (prisms built with irregular thickness of the stone units)

Table 9: Dimensions of a prism from group B (prisms built with irregular thickness of stone units) with $100 \times 100 \mathrm{~mm}$ cross section

\begin{tabular}{lccccc}
\hline Prism type & $\begin{array}{c}\text { Stone unit breadth } \\
\text { (Prism breadth) a (mm) }\end{array}$ & $\begin{array}{c}\text { Stone unit } \\
\text { height b }(\mathrm{mm})\end{array}$ & $\begin{array}{c}\text { Stone unit } \\
\text { thickness }(\mathrm{mm})\end{array}$ & $\begin{array}{c}\text { Prism thickness } \\
\mathrm{c}(\mathrm{mm})\end{array}$ & Prism height (mm) \\
\hline $\mathrm{b}$ & 100 & 100 & $25-68$ & 100 & 320 \\
\hline
\end{tabular}

Table 10: Dimensions of a prism from group B (prism built with irregular thickness of stone units) with $100 \times 100 \mathrm{~mm}$ cross section

\begin{tabular}{lccccc}
\hline Prism type & $\begin{array}{c}\text { Stone unit breadth } \\
\text { (Prism breadth) a (mm) }\end{array}$ & $\begin{array}{c}\text { Stone unit } \\
\text { height } \mathrm{b}(\mathrm{mm})\end{array}$ & $\begin{array}{c}\text { Stone unit } \\
\text { thickness }(\mathrm{mm})\end{array}$ & $\begin{array}{c}\text { Prism thickness } \\
\mathrm{c}(\mathrm{mm})\end{array}$ & Prism height (mm) \\
\hline $\mathrm{b}$ & 100 & 50 & $15-60$ & 100 & 170 \\
\hline
\end{tabular}

Strain measurements: Some of the tested prisms were fitted by strain measurements to study the relationship between stresses and strains. Dial gauges were used to determine the change of length for located lengths on prisms while a 'demec' mechanical strain gauge device was used to measure strain on stone and concrete faces by pre-located demec points with gauge lengths of $50 \mathrm{~mm}$.

The location of demec points on the stone face of the prisms are shown in Fig. 3-10. The location of demec points on the concrete face are shown in Fig. 7. The dial gauge locationsare shown in Fig. 3 and Fig. 4.
Testing procedure: Prior to testing, the top face for all prisms were grounded using an electrical disc grinder to ensure smooth and leveled surface of contact with the upper and lower steel plates.

All prisms were tested using a $1300 \mathrm{kN}$ capacity hydraulic testing machine in axial compression. The tests were carried on in accordance with BS 6073: part 1: 1981. For all prims the load was transferred from the machine base through $40 \mathrm{~mm}$ steel plates. 


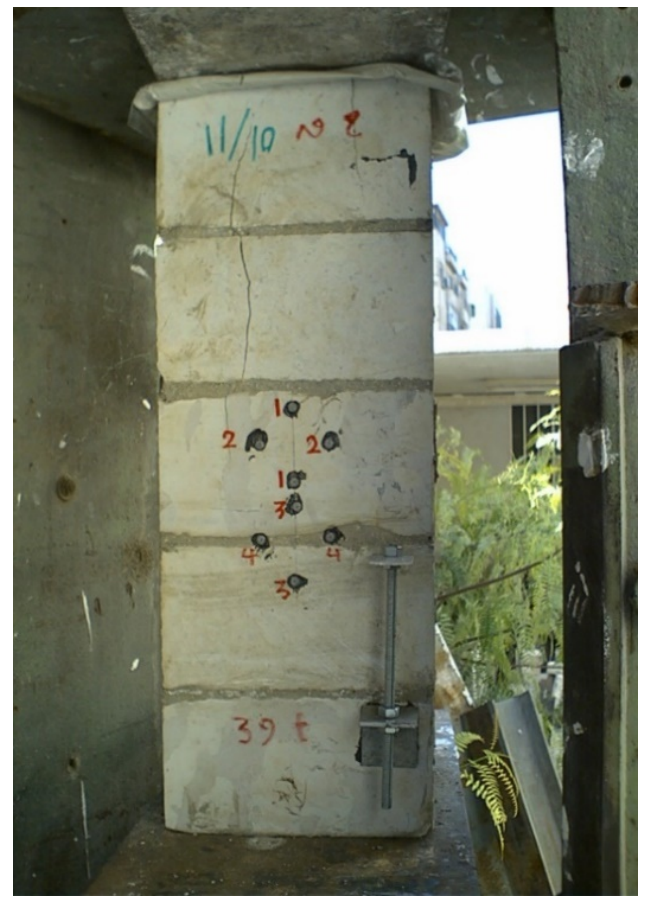

Fig. 3: Prism type d built with irregular thickness of stone units (with $200 \times 150 \mathrm{~mm}$ cross section) after failure

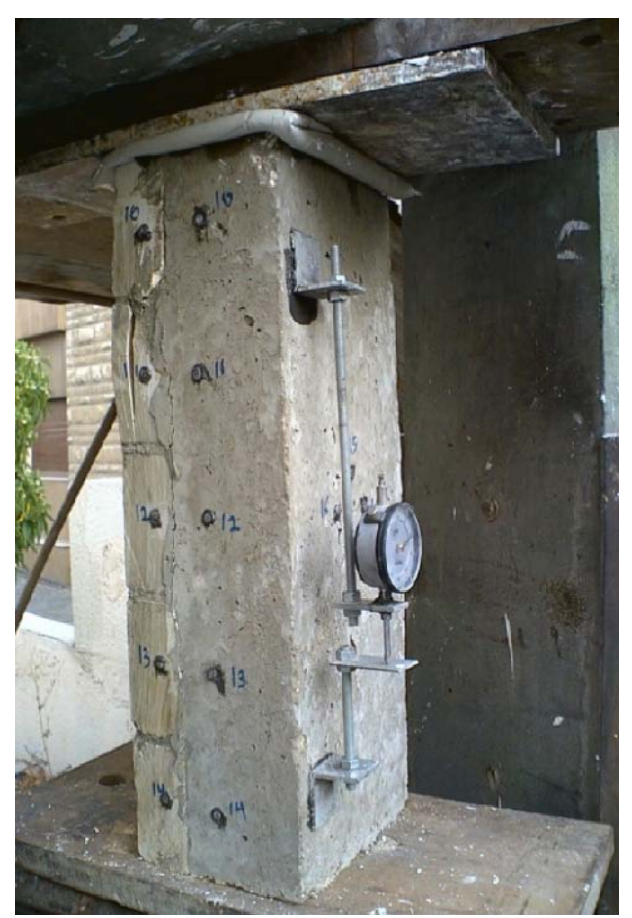

Fig. 4: Prism typed built with regular thickness of stone units (with $200 \times 150 \mathrm{~mm}$ cross section) after failure

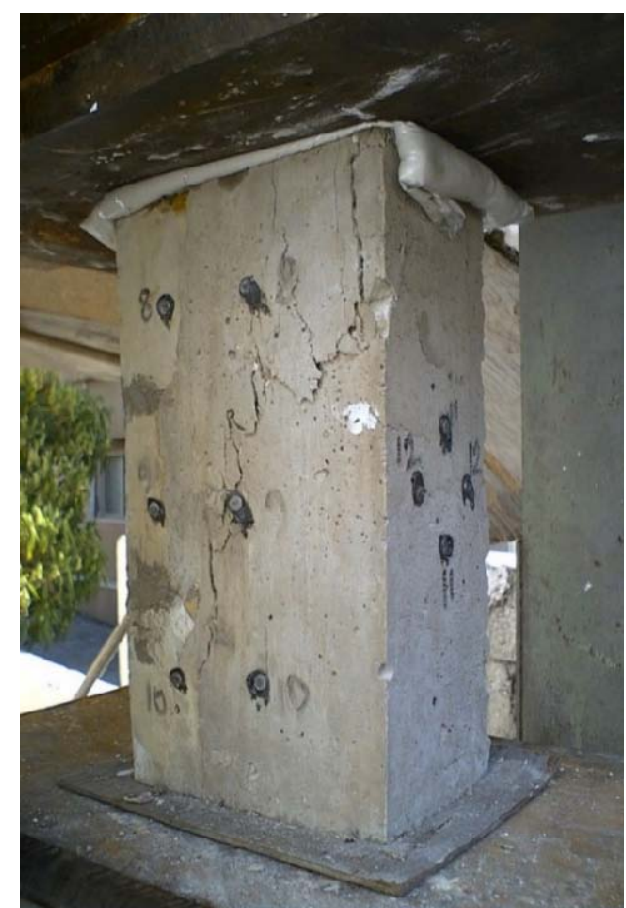

Fig. 5: Prism type b built with irregular thickness of stone units (with $100 \times 150 \mathrm{~mm}$ cross section) after failure

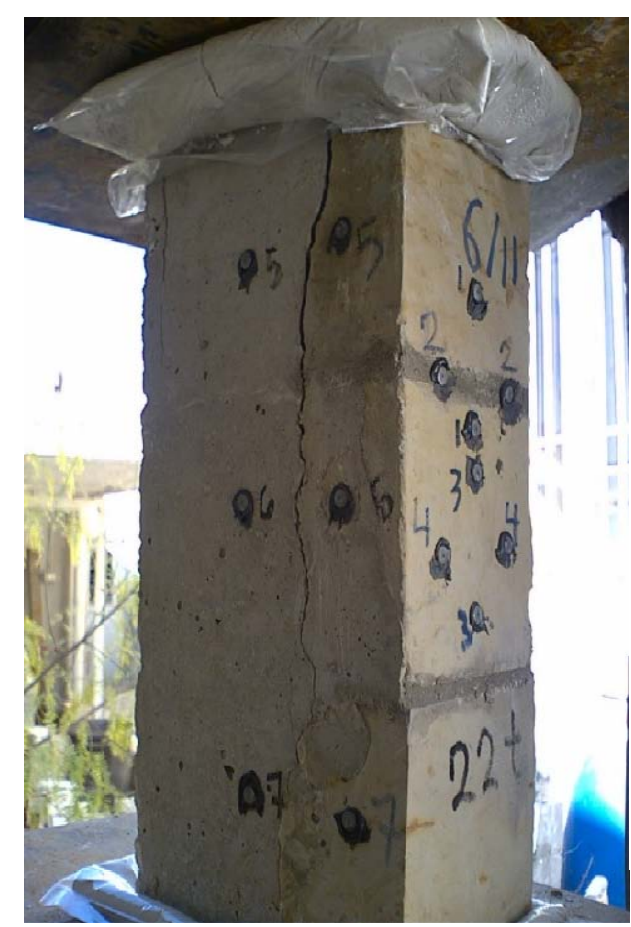

Fig. 6: Prism type b built with irregular thickness of stone units (with $100 \times 150 \mathrm{~mm}$ cross section) after failure 


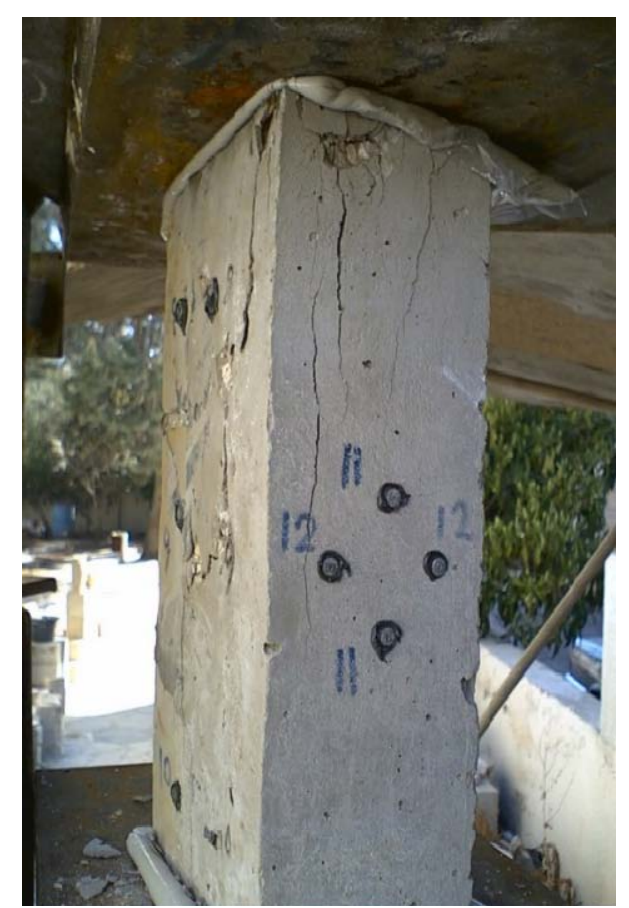

Fig. 7: Prism type b built with irregular thickness of stone units (with $100 \times 150 \mathrm{~mm}$ cross section) after failure

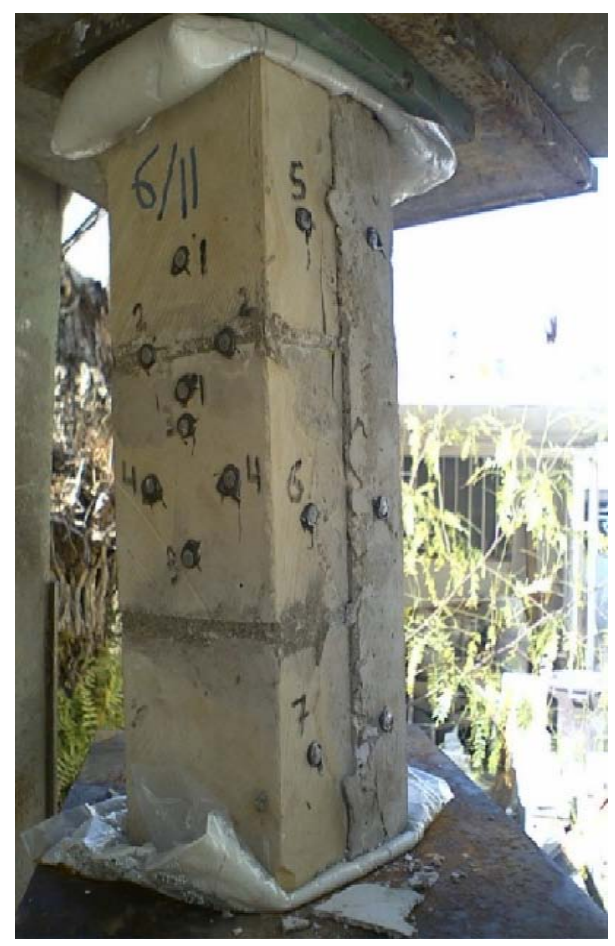

Fig. 8: Prism type b built with regular thickness of stone units (with $100 \times 100 \mathrm{~mm}$ cross section) after failure

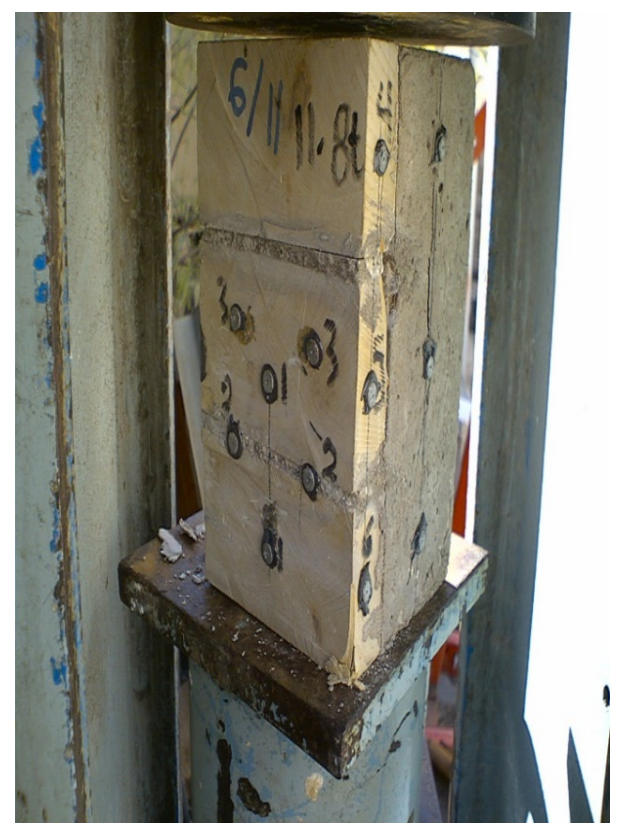

Fig. 9: Prism type $b$ built with regular thickness of stone units (with $100 \times 100 \mathrm{~mm}$ cross section and stone thickness of $25 \mathrm{~mm}$ ) after failure

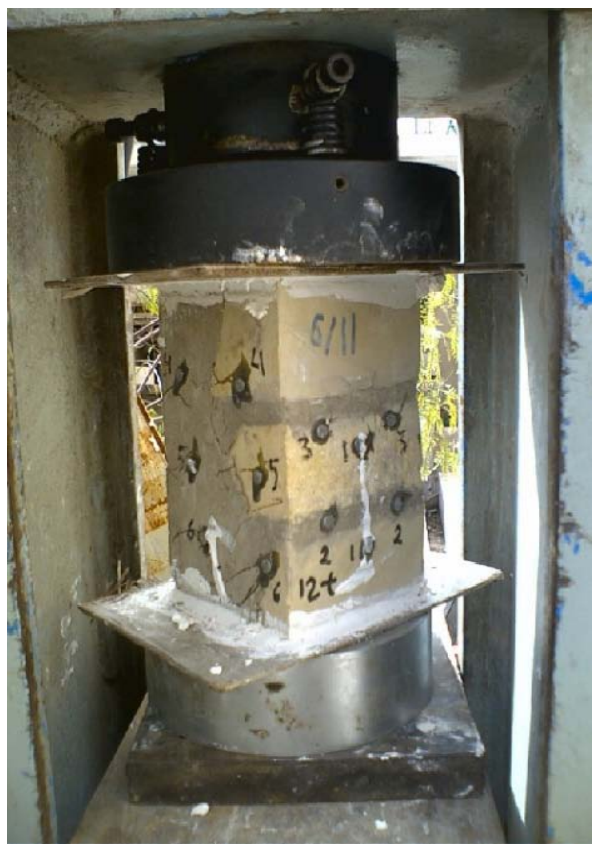

Fig. 10: Prism type $\mathrm{b}$ built with irregular thickness of stone units (with $100 \times 100 \mathrm{~mm}$ cross section) after failure

\section{RESULTS AND DISCUSSION}

The results of stone compressive strength, water absorption and density are given in Table 1 . The results 
J. Eng. Applied Sci., 15 (4): 982-989, 2020

Table 11: Average compressive strength for group A prisms (prisms built with regular thicknesses of stones)

\begin{tabular}{lccccc}
\hline Prism types & Prism breadth (mm) & Prism thickness (mm) & Prism height (mm) & No. of tested prisms & $\begin{array}{c}\text { Average compressive } \\
\text { strength }\left(\mathrm{N} \mathrm{mm}{ }^{-2}\right)\end{array}$ \\
\hline a & 200 & 150 & 210 & 6 & 19.8 \\
b & 200 & 150 & 320 & 7 & 17.7 \\
c & 200 & 150 & 430 & 1 & 11.9 \\
d & 200 & 150 & 540 & 2 & 13.6 \\
e & 200 & 150 & 650 & 2 & 10.3 \\
b & 100 & 150 & 320 & 3 & 15.8 \\
b & 100 & 100 & 320 & 3 & 19.8 \\
b & 100 & 150 & 170 & 2 & 18.4 \\
b & 100 & $100^{*}$ & 170 & 5 & 15.0 \\
b & 100 & & & & \\
"Stone thickness $25 \mathrm{~mm}$ & & & &
\end{tabular}

"Stone thickness $25 \mathrm{~mm}$

Table 12: Average compressive strength for group B prisms (prisms built with irregular thicknesses of stones)

\begin{tabular}{lccccc}
\hline Prism types & Prism breadth (mm) & Prism thickness $(\mathrm{mm})$ & Prism height $(\mathrm{mm})$ & No. of tested prisms & $\begin{array}{c}\text { Average compressive } \\
\left.\text { strength }(\mathrm{N} \mathrm{mm})^{-2}\right)\end{array}$ \\
\hline a & 200 & 150 & 210 & 9 & 18.60 \\
b & 200 & 150 & 320 & 18 & 13.80 \\
c & 200 & 150 & 430 & 4 & 12.40 \\
d & 200 & 150 & 540 & 4 & 11.10 \\
e & 200 & 150 & 650 & 4 & 11.60 \\
b & 100 & 150 & 320 & 3 & 12.70 \\
b & 100 & 100 & 320 & 6 & 7.15 \\
b & 100 & 100 & 170 & & 12.80 \\
\hline
\end{tabular}

Table 13: Strain readings obtained near failure for group A prisms (with $200 \times 150 \mathrm{~mm}$ cross sections)

\begin{tabular}{|c|c|c|c|c|c|c|c|c|}
\hline \multirow[b]{3}{*}{$\begin{array}{l}\text { Prism } \\
\text { types }\end{array}$} & \multicolumn{6}{|c|}{ Strain measured by using mechanical strain gauges ( $50 \mathrm{~mm}$ in length) } & \multicolumn{2}{|c|}{$\begin{array}{l}\text { Strain measured by using } \\
\text { dial gauges that measures the } \\
\text { change of length over } 0.67 \text { to } \\
0.75 \text { of the prism's height }\end{array}$} \\
\hline & \multicolumn{2}{|l|}{ Stone } & \multicolumn{2}{|l|}{ Mortar joint } & \multicolumn{2}{|l|}{ Concrete } & Stone face & Concrete face \\
\hline & $\begin{array}{l}\text { Vertical strain } \\
\left(\mathrm{x} 10^{-5}\right)\end{array}$ & $\begin{array}{l}\text { Horizontal strain } \\
\left(\mathrm{x} 10^{-5}\right)\end{array}$ & $\begin{array}{l}\text { Vertical strain } \\
\left(\mathrm{x} 10^{-5}\right)\end{array}$ & $\begin{array}{l}\text { Horizontal strain } \\
\quad\left(\mathrm{x} 10^{-5}\right)\end{array}$ & $\begin{array}{l}\text { Vertical strain } \\
\quad\left(\mathrm{x} 10^{-5}\right)\end{array}$ & $\begin{array}{l}\text { Horizontal strain } \\
\quad\left(\mathrm{x} 10^{-5}\right)\end{array}$ & $\begin{array}{l}\text { Vertical } \\
\text { strain }\end{array}$ & $\begin{array}{l}\text { Vertical } \\
\text { strain }\end{array}$ \\
\hline $\mathrm{a}$ & 69.4 & 19.8 & 263.6 & 210.0 & 231.9 & 107.00 & 0.0017 & 0.0042 \\
\hline b & 43.6 & 25.7 & 572.0 & 218.0 & 235.8 & 89.20 & 0.0034 & 0.0043 \\
\hline c & 61.4 & 396 & 67.4 & 75.3 & 116.1 & 200.10 & 0.0036 & 0.0046 \\
\hline d & 61.4 & 21.8 & 204.1 & 81.2 & 130.8 & 51.50 & 0.00165 & 0.0037 \\
\hline e & 87.2 & 16.0 & 65.4 & 269.6 & 164.0 & 29.73 & 0.00182 & 0.0029 \\
\hline
\end{tabular}

indicated that the stone specimens are within category II (Medium-density) as classified by ASTM C 568-89 (1992).

Table 11 give the results of the average compressive strength for group A prisms. The results show that prisms type a which are built from two courses has the highest compressive strengths. The table also show that smaller prisms has higher compressive strength than the larger ones.

Table 12 give the results of the average compressive strength for group B prisms. The results show that type aprism has the highest compressive strength. The results also show that smaller prismshave higher compressive strengths than the bigger ones. Comparing the compressive strengths obtained from the two groups, one can find thatthe results for group A slightly higher than those for group B.

Table 13 show the reading of strains obtained near failure for group A prisms. The results show that strains on the stone face were small compared to the strains on the concrete face.
Table 14 shows the reading of strains obtained near failure for group B prisms. Similar results were obtained when coming to the strains at stone faces where the strain readings were small.

Tables 13 and 14 show that strain readings obtained near failure for all prisms using dial gauges that measure the change of length over 0.67 to 0.75 of the prism's height has slightly changed in strain readings when the readings are obtained on the concrete face of the prisms.

Tables 15 and 16 shows the strains obtained near failure for prism with $100 \times 150 \mathrm{~mm}$ and $100 \times 100 \mathrm{~mm}$ cross section, respectively. The high horizontalstrain on the concrete face indicates that a vertical crack or more was taken place at the concrete face.

Table 17 and 18 shows strain readings obtained near failure for group B prisms. The high horizontal strain on the concrete face indicated that a vertical crack or more was taken place at the concrete face or near it. Table 19-20 give the strain reading obtained near failure for a prism of group A having $100 \times 100 \mathrm{~mm}$ cross section. 
Table 14: Some strain readings obtained near failure for group B prisms (with $200 \times 150 \mathrm{~mm}$ cross sections)

Strain measured by using mechanical strain gauges $(50 \mathrm{~mm}$ in length)

\begin{tabular}{|c|c|c|c|c|c|c|c|c|}
\hline \multirow[b]{2}{*}{$\begin{array}{l}\text { Prism } \\
\text { type }\end{array}$} & \multicolumn{2}{|l|}{ Stone } & \multicolumn{2}{|l|}{ Mortar joint } & \multicolumn{2}{|l|}{ Concrete } & \multirow{2}{*}{\begin{tabular}{l} 
Stone face \\
\hdashline Vertical \\
strain
\end{tabular}} & \multirow{2}{*}{\begin{tabular}{l} 
Concrete face \\
\hdashline $\begin{array}{l}\text { Vertical } \\
\text { strain }\end{array}$ \\
\end{tabular}} \\
\hline & $\begin{array}{l}\text { Vertical strain } \\
\left(\mathrm{x} 10^{-5}\right)\end{array}$ & $\begin{array}{l}\text { Horizontal strain } \\
\left(\mathrm{x} 10^{-5}\right)\end{array}$ & $\begin{array}{c}\text { Vertical strain } \\
\left(\mathrm{x} 10^{-5}\right)\end{array}$ & $\begin{array}{l}\text { Horizontal strain } \\
\left(\mathrm{x} 10^{-5}\right)\end{array}$ & $\begin{array}{l}\text { Vertical strain } \\
\left(\mathrm{x} 10^{-5}\right)\end{array}$ & $\begin{array}{l}\text { Horizontal strain } \\
\left(\mathrm{x} 10^{-5}\right)\end{array}$ & & \\
\hline $\mathrm{a}$ & 69.8 & 29.7 & 388.5 & 598.5 & 327 & 98.3 & 0.0017 & - \\
\hline b & 73.3 & 26.0 & 241.8 & 277.5 & 216.0 & 83.2 & 0.0017 & 0.0039 \\
\hline c & 37.6 & 45.6 & - & - & 166.0 & 71.4 & 0.0027 & 0.0033 \\
\hline d & 33.6 & 21.8 & 204.1 & 81.2 & 95.1 & 41.6 & 0.00201 & 0.0027 \\
\hline \multirow[t]{3}{*}{ e } & 41.6 & 18.6 & 188.1 & 66.0 & 128.8 & 55.4 & 0.0017 & 0.0037 \\
\hline & Strain me & asured by using me & chanical strain ge & auges $(50 \mathrm{~mm}$ in len & gth) & & & \\
\hline & Stone & & & Mortar joint & & Concrete & & \\
\hline $\begin{array}{l}\text { Prism } \\
\text { type }\end{array}$ & $\begin{array}{r}\text { Vertical st } \\
\left(\mathrm{x} 10^{-5}\right)\end{array}$ & $\begin{array}{r}\text { Horizon } \\
\quad(\mathrm{x} 10\end{array}$ & tal strain & $\begin{array}{l}\text { Vertical strain } \\
\left(\mathrm{x} 10^{-5}\right)\end{array}$ & $\begin{array}{l}\text { Horizontal strain } \\
\quad\left(\mathrm{x} 10^{-5}\right)\end{array}$ & $\begin{array}{r}\text { Vertical st } \\
\left(\mathrm{x} 10^{-5}\right)\end{array}$ & & $\begin{array}{l}\text { Horizontal strain } \\
\left(\mathrm{x} 10^{-5}\right)\end{array}$ \\
\hline $\overrightarrow{\mathrm{b}}$ & 59.4 & - & & 667.8 & 362.7 & 146.7 & & - \\
\hline
\end{tabular}

Table 15: Strain readings obtained near failure for a prismof group A (with $100 \times 150 \mathrm{~mm}$ cross section and $320 \mathrm{~mm}$ height)

Strain measured by using dial gauges that measures the change of length over 0.67 to 0.75 of the prism's height

Table 16: Strain readings obtained near failure for a prism of group A (with $100 \times 100 \mathrm{~mm}$ cross section and $320 \mathrm{~mm}$ height) Strain measured by using mechanical strain gauges ( $50 \mathrm{~mm}$ in length)

\begin{tabular}{|c|c|c|c|c|c|c|}
\hline \multirow[b]{2}{*}{$\begin{array}{l}\text { Prism } \\
\text { type }\end{array}$} & \multicolumn{2}{|l|}{ Stone } & \multicolumn{2}{|l|}{ Mortar joint } & \multicolumn{2}{|l|}{ Concrete } \\
\hline & $\begin{array}{c}\text { Vertical strain } \\
\left(\mathrm{x} 10^{-5}\right)\end{array}$ & $\begin{array}{l}\text { Horizontal strain } \\
\left(\times 10^{-5}\right)\end{array}$ & $\begin{array}{c}\text { Vertical strain } \\
\left(\mathrm{x} 10^{-5}\right)\end{array}$ & $\begin{array}{l}\text { Horizontal strain } \\
\left(\mathrm{x} 10^{-5}\right)\end{array}$ & $\begin{array}{c}\text { Vertical strain } \\
\left(\mathrm{x} 10^{-5}\right)\end{array}$ & $\begin{array}{l}\text { Horizontal strain } \\
\left(\mathrm{x} 10^{-5}\right)\end{array}$ \\
\hline b & 27.7 & - & 323.1 & - & 47.5 & 1547 \\
\hline
\end{tabular}

Table 17: Strain readings obtained near failure for a prism of group B (with $100 \times 150 \mathrm{~mm}$ cross section and $320 \mathrm{~mm}$ height) Strain measured by using mechanical strain gauges ( $50 \mathrm{~mm}$ in length)

\begin{tabular}{|c|c|c|c|c|c|c|}
\hline \multirow[b]{2}{*}{$\begin{array}{l}\text { Prism } \\
\text { type }\end{array}$} & \multicolumn{2}{|l|}{ Stone } & \multicolumn{2}{|l|}{ Mortar joint } & \multicolumn{2}{|l|}{ Concrete } \\
\hline & $\begin{array}{l}\text { Vertical strain } \\
\quad\left(\mathrm{x} 10^{-5}\right)\end{array}$ & $\begin{array}{l}\text { Horizontal strain } \\
\left(\mathrm{x} 10^{-5}\right)\end{array}$ & $\begin{array}{l}\text { Vertical strain } \\
\left(\mathrm{x} 10^{-5}\right)\end{array}$ & $\begin{array}{l}\text { Horizontal strain } \\
\quad\left(\mathrm{x} 10^{-5}\right)\end{array}$ & $\begin{array}{l}\text { Vertical strain } \\
\left(\mathrm{x} 10^{-5}\right)\end{array}$ & $\begin{array}{l}\text { Horizontal strain } \\
\left.\text { (x } 10^{-5}\right)\end{array}$ \\
\hline b & 35.7 & 19.8 & 681.8 & 451.8 & 364.6 & 1101.9 \\
\hline
\end{tabular}

Table 18: Strain readings obtained near failure for a prism of group B (with $100 \times 100 \mathrm{~mm}$ cross section and $320 \mathrm{~mm}$ height) Strain measured by using mechanical strain gauges $(50 \mathrm{~mm}$ in length)

\begin{tabular}{|c|c|c|c|c|c|c|}
\hline \multirow[b]{2}{*}{$\begin{array}{l}\text { Prism } \\
\text { type }\end{array}$} & \multicolumn{2}{|l|}{ Stone } & \multicolumn{2}{|l|}{ Mortar joint } & \multicolumn{2}{|l|}{ Concrete } \\
\hline & $\begin{array}{l}\text { Vertical strain } \\
\left(\times 10^{-5}\right)\end{array}$ & $\begin{array}{l}\text { Horizontal strain } \\
\left(\mathrm{x} 10^{-5}\right)\end{array}$ & $\begin{array}{l}\text { Vertical strain } \\
\left(\mathrm{x} 10^{-5}\right)\end{array}$ & $\begin{array}{l}\text { Horizontal strain } \\
\left(\mathrm{x} 10^{-5}\right)\end{array}$ & $\begin{array}{l}\text { Vertical strain } \\
\left(\mathrm{x} 10^{-5}\right)\end{array}$ & $\begin{array}{l}\text { Horizontal strain } \\
\left(\times 10^{-5}\right)\end{array}$ \\
\hline $\mathrm{b}$ & 63.4 & 998.9 & 170.4 & - & 49.6 & 1129.7 \\
\hline
\end{tabular}

Table 19: Strain readings obtained near failure for a prism of group A (with $100 \times 100 \mathrm{~mm}$ cross section and $160 \mathrm{~mm}$ height) Strain measured by using mechanical strain gauges (50 $\mathrm{mm}$ in length)

\begin{tabular}{|c|c|c|c|c|c|c|}
\hline \multirow[b]{2}{*}{$\begin{array}{l}\text { Prism } \\
\text { type }\end{array}$} & \multicolumn{2}{|l|}{ Stone } & \multicolumn{2}{|l|}{ Mortar joint } & \multicolumn{2}{|l|}{ Concrete } \\
\hline & $\begin{array}{l}\text { Vertical strain } \\
\left(\mathrm{x} 10^{-5}\right)\end{array}$ & $\begin{array}{l}\text { Horizontal strain } \\
\left(\times 10^{-5}\right)\end{array}$ & $\begin{array}{l}\text { Vertical strain } \\
\left(\mathrm{x} 10^{-5}\right)\end{array}$ & $\begin{array}{l}\text { Horizontal strain } \\
\left(\mathrm{x} 10^{-5}\right)\end{array}$ & $\begin{array}{l}\text { Vertical strain } \\
\left(\mathrm{x} 10^{-5}\right)\end{array}$ & $\begin{array}{l}\text { Horizontal strain } \\
\quad\left(\mathrm{x} 10^{-5}\right)\end{array}$ \\
\hline $\mathrm{b}$ & No gauge & 113.0 & - & 212.1 & 315.1 & 818.56 \\
\hline
\end{tabular}

Table 20: Strain readings obtained near failure for a prism of group B (with $100 \times 100 \mathrm{~mm}$ cross section and $160 \mathrm{~mm}$ height)

\begin{tabular}{|c|c|c|c|c|c|c|}
\hline \multirow[b]{3}{*}{$\begin{array}{l}\text { Prism } \\
\text { type }\end{array}$} & \multicolumn{6}{|c|}{ Strain measured by using mechanical strain gauges ( $50 \mathrm{~mm}$ in length) } \\
\hline & \multicolumn{2}{|l|}{ Stone } & \multicolumn{2}{|l|}{ Mortar joint } & \multicolumn{2}{|l|}{ Concrete } \\
\hline & $\begin{array}{l}\text { Vertical strain } \\
\left(\mathrm{x} 10^{-5}\right)\end{array}$ & $\begin{array}{l}\text { Horizontal strain } \\
\left(\times 10^{-5}\right)\end{array}$ & $\begin{array}{l}\text { Vertical strain } \\
\left(\times 10^{-5}\right)\end{array}$ & $\begin{array}{l}\text { Horizontal strain } \\
\left(\mathrm{x} 10^{-5}\right)\end{array}$ & $\begin{array}{l}\text { Vertical strain } \\
\left(\mathrm{x} 10^{-5}\right)\end{array}$ & $\begin{array}{l}\text { Horizontal strain } \\
\left(\mathrm{x} 10^{-5}\right)\end{array}$ \\
\hline $\mathrm{b}$ & No gauge & 77.3 & 338.9 & 216.1 & 166.5 & 1092.1 \\
\hline
\end{tabular}




\section{CONCLUSION}

We can conclude that testing small prisms could be an alternative method that one can use instead of testing large scale prisms.

\section{AKNOWLEDGEMENTS}

This research has been carried out during sabbatical leave granted to the researcher (Nart M Naghoj) from Al-Balqa Applied University (BAU) during the academic year 2017/2018.

\section{REFERENCES}

ASTM C 170-90, 1992. Standard test method for compressive strength of dimension stone. American Society for Testing and Materials, West Conshohocken, Pennsylvania, USA.
ASTM C 568-89, 1992. Standard specification for limestone dimension stone. National Stone Institute, America.

ASTM C 97-90, 1992. Standard tests for absorption and bulk specific gravity of dimension stone. National Stone Institute, America.

Abdel-Halim, M.A., M.R. Basoul and R.A. Abdel-Karim, 1989. Structural evaluation of concrete-backed stone Masonry. Struct. J., 86: 608-614.

Abdel-Qader, N.M., 2002. Compressive strength of concrete-backed stone masonry prisms. Proceedings of the 6th International Conference on Concrete Technology for Developing Countries, October 21-24, 2002, Amman, Jordan, pp: 595-604.

Naghoj, N.M., 2013. The effect of height-to-width ratio on the strength of concrete-backed stone masonry prisms. Contemp. Eng. Sci., 6: 261-271. 